\title{
KEBIJAKAN 6 BULAN MASA CUTI MELAHIRKAN UNTUK MENGHINDARKAN PEKERJA MENGALAMI DEPRESI DAN STRES SAAT MEMBERIKAN ASI
}

\author{
Asep Prasetyo \\ Univesitas Islam Negeri (UIN) Syarif Hidayatullah Jakarta \\ E-mail: asepprasetyosmkpj@gmail.com
}

\begin{abstract}
Abstrak: Penelitian ini mencoba mengetahui pentingnya kebijakan memperpanjang hak cuti melahirkan bagi karyawan menjadi 6 bulan dibandingkan merevisi atau menetapkan hukum lain mengenai penyediaan Ruang ASI di tempat kerja. Penelitian ini penting dilakukan untuk mengetahui apakah kebijakan Ruang ASI yang selama ini diterapkan oleh Perusahaan telah memadai untuk menjamin terselenggaranya program ASI ekslusif serta sebagai bahan pertimbangan untuk melegalkan memperpanjang masa cuti melahirkan menjadi 6 bulan. Data lapangan didapat melalui survei online menggunakan aplikasi Google form yang dipublikasikan di dalam website Asosiasi Ibu Menyusui Indonesia (AIMI). Adapun studi kepustakaan juga dilakukan untuk mendapatkan informasi mengenai peraturan perundang-undangan yang mengatur tentang ASI, bagaimana terbentuknya ASI dan manfaatnya, serta kondisi yang dialami oleh seorang ibu saat melahirkan. Dalam penelitian ini ditemukan bahwa kebijakan memperpanjang masa cuti melahirkan lebih manusiawi dibandingkan dengan merevisi kebijakan Ruang ASI karena seorang ibu yang lebih fokus dalam mengasuh anak di awal pasca melahirkan lebih memberikan ketenangan dan kenyamanan. Sedangkan seorang ibu yang mendapatkan porsi cuti sedikit dan terbebani oleh pekerjaan kantor cenderung dapat menyebabkan stres yang dapat mengurai kualitas dan produksi ASI.
\end{abstract}

Kata Kunci: cuti melahirkan, Ruang ASI, dukungan suami

\section{PENDAHULUAN}

Hak dan kewajiban pekerja telah diatur dalam Undang-Undang nomor 13 tahun 2003 tentang ketenagakerjaan. Undang-Undang ini dimaksudkan untuk melindungi dan menjamin hak-hak dasar pekerja untuk mendaptkan kesempatan yang sama tanpa adanya diskriminasi untuk mewujudkan kesejahteraan pekerja itu sendiri.

Perempuan sebagai seorang tenaga kerja mengalami pengalaman yang tidak sama dengan laki-laki, seperti mestruasi, hamil dan melahirkan. Oleh karena itu dalam rangka melindungi pekerja perempuan dari diskriminasi dan melindungi fungsi reproduksinya yang sesuai dengan kodrat maka Pemerintah menetapkan secara khusus dalam Undang-Undang
Ketenagakerjaan terkait hak-hak apa saja yang diterima seorang perempuan ketika mestruasi, hamil dan melahirkan. Sayangnya cuti melahirkan bagi pekerja di Indonesia sangat kurang.

Di Indonesia, cuti melahirkan bagi seorang pekerja perempuan pasca melahirkan hanyalah 1.5 bulan sebagaimana yang telah diatur dalam pasal 82 Undang-Undang Ketenagakerjaan. Kebijakan ini sangat merugikan seorang ibu ketika kedekatan emosional di antara ibu dan anak sedang dibangun, seorang ibu diharuskan untuk kembali menghadapi rutinitas di kantor. $\mathrm{Hal}$ ini sangatlah berlawanan dengan kebijakan Pemerintah yang telah mencanangkan program ASI ekslusif 6 bulan lamanya. Sebagai perbandingan, negara dengan ekonomi yang lebih mapan dari Indonesia telah memberikan 
masa cuti melahirkan lebih panjang bagi pekerja perempuannya, sebagai contoh Jepang telah memberikan kesempatan kepada karyawatinya untuk cuti melahirkan selama satu tahun dan mendapatkan gaji penuh selama 34 minggu.

Adapun di Indonesia terdapat sebuah kesan bahwa tugas mendidik dan merawat seorang anak adalah tugas seorang perempuan. $\mathrm{Hal}$ ini bisa terlihat dengan pemberian waktu yang sedikit bagi seorang suami untuk membantu istrinya pasca melahirkan. Kebijakan ini dikenal dengan istilah Paternity Leave, yang dalam bahasa Indonesia berarti hak cuti yang diberikan kepada suami karena istri melahirkan. Mengacu kepada Pasal 93 ayat 4 huruf e Undang-Undang Ketenagakerjaan, seorang pekerja laki-laki hanya mendapatkan 2 hari masa cuti yang dibayar penuh sedangkan untuk mendapatkan waktu lebih seorang karyawan harus mengambil masa cuti tahunannya dan tidak mendapatkan bayaran.

Dalam tulisan ini penulis tertarik untuk membahas manfaat kebijakan memperpanjang masa cuti kelahiran pasca melahirkan dari 1.5 bulan menjadi 6 bulan dibandingkan dengan membuat atau merevisi hukum-hukum terkait menyusui atau ruang ASI yang dalam praktiknya banyak terjadinya penyelewengan kebijakan. Dan penulis merasa perlu untuk adanya sebuah perundang-undangan atau pasal khusus yang memperbolehkan seorang suami untuk membantu istrinya lebih lama pada masa-masa awal pasca melahirkan. Oleh karena itu untuk melindungi dan menciptakan sebuah generasi penerus bangsa yang lebih sehat dan kuat tidak hanya bisa dibangun oleh satu orang yang dalam kasus ini adalah Ibu, tetapi dibutuhkannya bantuan-bantuan lain seperti suami yang siap mendukung, Perusahaan yang bersahabat dan Perundang-undangan yang melegalkannya.
Menurut kamus Oxford Reference online, Feminist Legal Theory adalah:

A broad movement that seeks to show how conventional legal theory, far from being gender-blind, ignores the position and perspective of women. Feminist write examine the inequalities to be found in the criminal law (especially in rape and domestic violence), family law, contract, tort, property, and others branches of the substantive law, including aspects of public law.

Adapun pengkajian kritis hukum terkait dengan perspektif feminis memperhatikan lima hal sebagai berikut:

1. Pengalaman perempuan. Pengalaman perempuan ini penting sebagai dasar pertimbangan bagi penalaran hukum baru.

2. Bias gender secara implisit. Hal ini terlihat melalui berbagai perundangan yang terkesan netral dan objektif, namun ternyata tidak demikian.

3. Ikatan ganda dan dilema dari perbedaan. Tidak tersedianya pilihan bagi perempuan sehingga kemudian mau tidak mau harus mengambil pilihan yang sesungguhnya merugikan dan tidak adil baginya, contoh: perempuan korban KDRT, perempuan dilema antara karir dan pekerjaan rumah tangga.

4. Reproduksi model dominasi laki-laki. Pembentuk undang-undang atau kebijakan seringkali mereproduksi peraturan yang seolah-olah berpihak pada perempuan, namun sesungguhnya tidak lebih baik dan tidak sungguh-sungguh dimaksudkan untuk memperbaiki kondisi perempuan. Misalnya, perda tentang larangan perempuan keluar malam, alasannya untuk melindungi, tapi sesungguhnya lebih untuk mengontrol dan membatasi. 


\section{5-191 | HARKAT: Media Komunikasi Islam Tentang Gender dan Anak, 11 (2), 2015}

5. Membuka pilihan-pilihan bagi perempuan. Hukum beranggapan bahwa pilihan yang dimiliki (dipilih oleh) perempuan berasal dari kenyataan biologisnya, khususnya kodrat alamiahnya yang akhirnya memotivasi perempuan untuk menjalankan kegiatan tradisional sehingga hukum menganggap perempuan bertanggungjawab atas hal tersebut. Pilihan yang dipilih perempuan tersebut seringkali dipengaruhi oleh kesempatan yang tersedia untuknya dan kultur dominan yang ada di antara mereka. Perempuan yang memilih mengembangkan karir dan meninggalkan pekerja domestik, dianggap sebagai „meninggalkan kodratnya (Savitri, dalam Irianto (ed.), 2006: 46-49).

Sedangkan tujuan terbentuknya sebuah hukum menurut Subekti (dalam Kansil 1986:41) adalah, melayani tujuan Negara tersebut dengan menyelenggarakan "keadilan" dan "ketertiban" dengan syarat yang pokok untuk mendatangkan kemakmuran dan kebahagiaan. Keadilan selalu mengandung unsur “penghargaan”, "penilaian”, atau

“pertimbangan” dan karena itu [hukum] lazim dilambangkan dengan suatu "neraca keadilan”.

Menurut Agusmidah (2010:70) ada dua alasan penting mengapa terdapat pasal khusus dalam peraturan ketenagakerjaan yang materi dan substansinya dikhususkan bagi pekerja perempuan, yakni:

1. Mencegah timbulnya perlakuan diskriminasi (pembedaan, pengecualian, dan pengutamaan) yang berakibat mengurangi persamaan kesempatan atau perlakuan dalam pekerjaan atau jabatan.

2. Melindungi pekerja perempuan untuk melangsungkan dan melaksanakan tugas reproduksinya sesuai kodrat, tanpa harus kehilangan kesempatan hak atas pekerjaan.
Oleh karena itu, untuk melindungi seorang pekerja perempuan dari diskriminasi dan melindungi terlaksanannya tugas reproduksi perempuan maka dibuatlah Undang-Undang yang mengatur agar hak-hak perempuan terlaksana.

ASI adalah makanan yang ideal bagi bayi untuk beberapa bulan ia dilahirkan. ASI memiliki zat antiinfeksi yang membantu melindungi bayi dari serangan kuman dan virus, serta melindungi bayi dari diare dan penyakit lain (Widodo, 2009:43).

Untuk menciptakan sebuah generasi yang lebih cerdas dan pandai berilah ASI minimal 6 bulan (ASI ekslusif) dan maksimal 24 bulan apabila seorang ibu masih menginginkan dan merasa bahagia (Boedirman, 2009:2-3).

Pembentukan dan pengeluaran ASI berdasarkan Refleks let down (milk ejection reflex) adalah rangsangan yang berasal dari isapan bayi. Proses terbentuknya adalah rangasan dari isapan bayi yakni proklatin dilanjutkan ke neurohipofise (hipofise posterior) yang kemudian dikeluarkan oksitosin. Ketika oksitosin telah sampai pada alveoli maka akan mempengaruhi sel miopitelium dan selanjutnya kontraksi dari sel mioepitelium akan memeras air susu yang masuk ke mulut bayi.

Faktor-faktor yang meningkatkan refleks let down adalah Melihat bayi, Mendengarkan suara bayi, Mencium bayi, Memikirkan untuk menyusui bayi.

Faktor-faktor yang menghambat refleks let down adalah Stres seperti Keadaan bingung/pikiran kacau, Takut, Cemas

Stres dari ibu yang menyusui mengakibatkan tidak sempurnanya refleks let down maka akan terjadi penumpukan air susu di dalam alveoli yang secara klinis tampak payudara membesar. Payudara yang besar dapat berakibat abses, gagal untuk menyusui dan rasa sakit. Rasa sakit ini merupakan stres lagi bagi seorang ibu 
yang menyebabkannya akan semakin bertambah stres (Machfuddin, 2004).

Dalam bab 1 pasal 1 ayat 3 Permenkes nomor 15 tahun 2013 bab 1 pasal 1 ayat 3 dijelaskan bahwa yang dimaksud dengan Ruang ASI adalah ruangan yang dilengkapi dengan prasarana menyusui dan memerah ASI yang digunakan untuk menyusui bayi, memerah ASI, menyimpan ASI perah, dan/atau konseling menyusui/ASI.

Sebuah ruangan ASI haruslah memiliki sarana dan fasilitas yang memadai sekaligus higienis. Sebuah ruang ASI dikategorikan memadai apabila di dalamnya terdapat:

1. Memiliki ventilasi dan sirkulasi udara yang cukup;

2. Lingkungan cukup tenang jauh dari kebisingan;

3. Ada pintu yang dapat dikunci, yang mudah dibuka/ditutup;

4. Tersedia westafel dengan air mengalir untuk cuci tangan dan mencuci peralatan.

5. Bebas potensi bahaya di tempat kerja termasuk bebas polusi;

6. Lemari pendingin untuk menyimpan ASI;

7. Meja tulis dan kursi sandaran untuk ibu memerah ASI;

8. Alat pengatur suhu ruangan, $\mathrm{d} s \mathrm{~b}$.

\section{Metode Penelitian}

Penelitian ini menggunakan metode kualitatif deskriptif. Data didapat melalui dua cara, yakni: studi kepustakaan dan survei online dengan menggunakan aplikasi google form. Studi kepustakaan dilakukan dengan melakukan penulusuran literatur terkait peraturan perundang-undangan mengenai hak menyusui bagi pekerja/buruh perempuan di tempat kerja, buku-buku yang berkaitan, serta jurnal dan artikel yang dapat diunduh dan dibaca secara online. Kemudian penulis melakukan analisis dari materi dan teori yang didapatkan dengan keadaan nyata yang didapatkan dari data kuisioner online.

Untuk mendapatkan data lapangan berupa kebijakan perusahaan dan bagaimana pengetahuan seorang pekerja/buruh perempuan terhadap hak menyusui/memerah ASI di tempat kerja. Penulis bekerja sama dengan Asosiasi Ibu Menyususi Indonesia (AIMI) melakukan survei melalui kuisioner online yang diselenggarakan dari tanggal 01 September sampai dengan 16 September 2015 yang dipublikasikan di Web AIMI didapat 1212 responden yang berpartisipasi dalam survei ini. Pertanyaan yang diajukan berupa pengetahuan pekerja/buruh perempuan terhadap undang-undang yang menyangkut hak menyusui atau memerah di tempat kerja dan kebijakan ruang ASI tempat bekerja.

\section{HASIL DAN PEMBAHASAN}

Untuk menunjukkan bahwa tidak diperlukaannya sebuah pembaharuan dalam perundang-undangan terkait Ruang ASI di perusahaan. Penulis mencoba memaparkan bagaimana kebijakan yang telah diambil oleh banyak Perusahaan di Indonseia.

Penyediaan Ruang ASI merupakan sebuah kebijakan Pemerintah guna melindungi program ASI ekslusif yang telah dicanangkan, tetapi kebanyakan kebijakan terkait pengadaan Ruang ASI sendiri tidaklah sesuai dengan Peraturan Menteri Kesehatan (Permenkes) nomor 15 tahun 2013 tentang tata cara penyediaan fasilitas khusus menyusui dan/atau memerah Air Susu Ibu. Hal ini bisa diamati dari hasil statistik kuisoner berikut. 


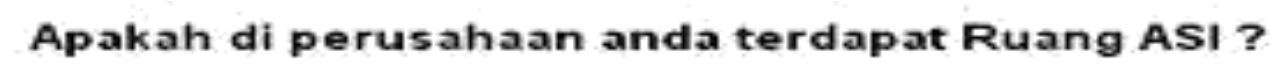
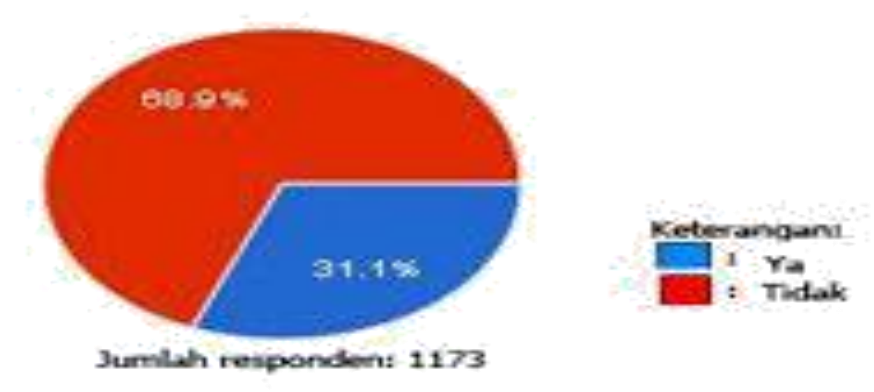

Gambar 1

\section{Apakah ruangan ASI tersebut merupakan ruangan permanen atau hanya ruangan serbaguna?}
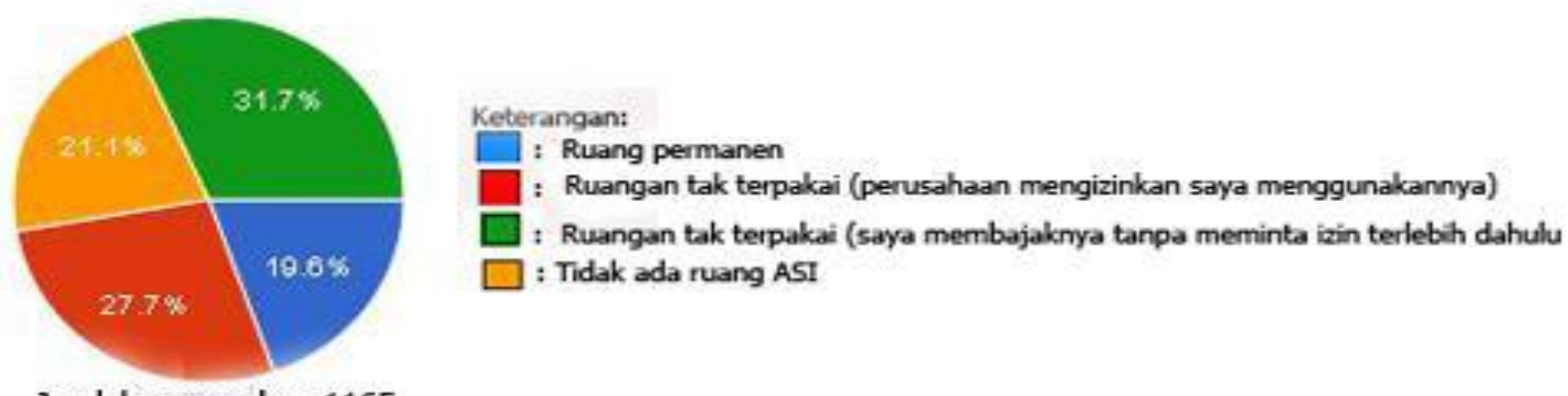

Jumlah responden: 1165

Gambar 2

\section{Apakah ruang ASI tersebut memilik fasilitas yang memadait dan hiegenis?}

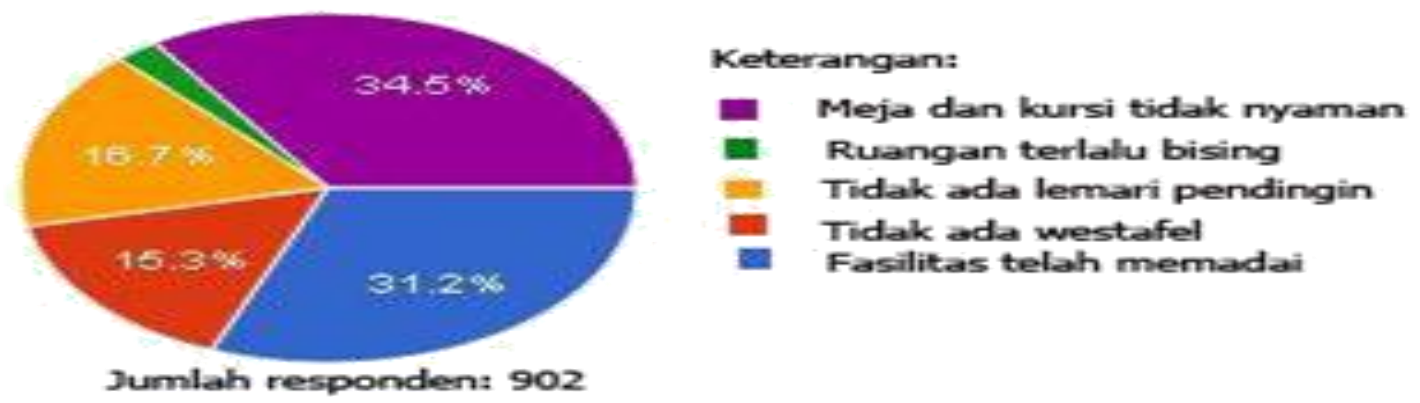

Gambar 3

Berdasarkan gambar 1 diketahui bahwa hanya $31.1 \%$ dari 1173 responden yang mendapatkan fasilitas ruang ASI di tempatnya bekerja. Sedangkan $68.9 \%$ menyatakan tidak mendapatkan tempat untuk menyusui atau memerah ASI. Hal yang menarik untuk diteliti lebih lanjut adalah bagaimana Perusahaan menyediakan ruang ASI bagi pekerjanya.
Dan Berdasarkan hasil statistik pada data kuisioner di atas maka didapat data berupa; 19.6\% dari 1165 responden menyatakan ruang ASI yang digunakan merupakan ruang permanen yang dari sejak dibangun diperuntukan untuk Ruang ASI. Sedangkan $27.7 \%$ responden menyatakan diperbolehkan menggunakan ruangan tak terpakai, dan $21.1 \%$ menggunakan ruangan untuk menyusui atau memerah ASI 
tanpa izin terlebih dahulu dan $31.7 \%$ menyatakan tidak mendapatkan ruang ASI.

Apabila menilik kedua hasil statistik di atas maka terdapat sebuah keanehan, yakni pada gambar 1 terlihat lebih dari setengah, tepatnya $68.9 \%$ responden menyatakan tidak mendapatkan Ruang ASI sedangkan pada gambar 2 terlihat bahwa setengah dari responden mendapatkan Ruang ASI, baik itu Ruang permanen atau diperbolehkan menggunakan ruangan tak terpakai. Kemungkinan yang terjadi adalah pekerja merasa bahwa ruang yang diberikan tidak memiliki sarana dan prasarana yang memadai sehingga ruang ASI tampak seperti ruangan pada umumnya. Apabila melihat data hasil statistik terhadap kuisioner di bawah ini maka dapat menguatkan pernyataan bahwa perusahaan tidak memberikan ruang yang layak.

Berdasarkan data hasil statistik atas kuisoner pada gambar 3 maka didapat data sebagai berikut: $31.2 \%$ dari 902 responden menjawab telah mendapatkan fasilitas memadai. Sedangakan $2.3 \%$ menyatakan mendapatkan ruangan terlalu bising, $15.3 \%$ mendapatkan ruangan tidak berwestafel sehingga tidak dapat mencuci tangan dan peralatan di Ruang ASI, $34.5 \%$ menyatakan tidak mendapatkan meja dan kursi yang nyaman, dan $15.3 \%$ tidak mendapatkan lemari pendingin.

Dari data ini terlihat bahwa perusahaan tidak menyediakan fasilitas yang higienis bagi karyawan melihat tidak adanya westafel yang berfungsi untuk menyuci peralatan dan botol, atau tidak adanya sofa atau kursi yang nyaman guna membuat pekerja agar lebih santai, atau bahkan perusahaan tidak memberikan fasilitas pendingin untuk menaruh hasil ASI perah.

Hemat penulis, apabila berkaca dari ketiga hasil kuisioner di atas maka masih sangat lemah kebijakan yang dilakukan oleh perusahaan dalam melindungi hak menyusui pekerjanya. Oleh karena itu penulis lebih setuju bahwa untuk melindungi program ASI ekslusif 6 bulan maka yang diperlukan bukanlah merevisi undangundang yang telah ada atau membuat undangundang dengan maksud sama guna menguatkan kebijakan yang telah ada.

Memperpanjang waktu cuti melahirkan merupakan jawaban yang tepat untuk menjawab permasalahan yang ada. Apabila Pemerintah melegalkan peraturan tentang masa cuti melahirkan selama 6 bulan maka akan memudahkan Pemerintah dalam menjalani program ASI ekslusif. Sebuah hal yang sangat disayangkan dengan sudah diketahuinya manfaat ASI terhadap kesahatan dan tumbuh kembang anak, Pemerintah dan Perusahaan masih saja bertahan dengan memberikan kebijakan cuti melahirkan hanya 1.5 bulan lamanya.

Sebagaimana yang telah dijelaskan dalam Feminist Legal Theory bahwa hukum yang telah dibuat tidak mempertimbangkan pengalaman perempuan. Adapun pengalaman perempuan yang tidak diperhitungkan oleh undang-undang adalah kecenderungan seorang ibu menagalami depresi pasca melahirkan. Depresi bisa terjadi dikarenakan ketidaktahuan seorang ibu dalam merawat bayinya dan ketidaksiapaan beban dan tanggung jawab sebagai seorang ibu. Moore (2002) menyatakan rentang waktu terjadinya depresi pasca melahirkan adalah 2 minggu sampai 6 bulan dan bila tidak segera ditangani dapat bertahan beberapa bulan bahkan tahunuan.

Mengacu pada kondisi seperti ini maka dirasakan bahwa masa cuti melahirkan sebagaimana yang ditetapkan dalam pasal 82 Undang-Undang nomer 13 tahun 2003 tentang Ketenagakerjaan selama 1.5 bulan pasca melahirkan dirasa kurang. Belum habis pikiran dan hati tercurahkan untuk buah hati, seorang ibu harus dipaksa kembali bekerja.

Adapun memerah ASI di tempat kerja sebagaimana yang telah diatur di UndangUndang belum dapat berbuat banyak. Sebagaimana yang telah dijelaskan dalam 
landasan teori mengenai terbentuknya ASI berdasarkan refleks let down bahwa faktor-faktor stres pada ibu dapat menyebabkan menurunan produksi ASI. Maksud penulis menjelaskan kembali konsep ini adalah bahwa tidak menutup kemungkinan bahwa seorang wanita karir mengalami stres diakibatkan pekerjaan yang menupuk di kantor dan di rumah diharuskan untuk merawat anak. Kemudian, apa yang terjadi ketika seorang ibu yang masih mengalami depresi pasca melahirkan dan masa cuti melahirkannya telah habis terpaksa masuk kerja lalu memerah air susunya?

Berdasarkan faktor-faktor peningkatan refleks let down terhadap terbentuknya ASI maka dapat ditemukan bahwa kebijakan memperpanjang masa cuti melahirkan lebih bermanfaat dibandingkan memperbaharui atau menambahkan Undang-Undang terkait Ruang ASI atau hak menyusui, yakni ketika seorang ibu bisa melihat, mendengar, mencium dan menyusui bayi, hal itu dapat meningkatkan produksi ASI. Bandingkan dengan memerah ASI di Ruang ASI, dengan memerah mungkin program ASI ekslusif masih bisa dipenuhi, tetapi seorang ibu yang menyusui bayinya secara langsung mendapatkan manfaat lebih yakni terjalinnya emosi yang kuat antara ibu dan bayi.

Di Indonesia sendiri, perusahaan yang telah menetapkan kebijakan cuti melahirkan 6 bulan dengan gaji dibayar secara penuh hanya Opal Communications. Hal ini menandakan bahwa perusahaan Indonesia sebenarnya mampu untuk menerapkan kebijakan cuti melahirkan lebih lama dari yang telah diatur saat ini, yakni 1.5 sebelum dan sesudah yang diakumulatifkan menjadi 3 bulan.

Kemudian kenapa masih banyak perusahaan masih enggan menerapkan kebijakan cuti lebih panjang dari yang ditetapkan? Triana Sofiani (PALESTReN Vol.3, No. 1 Juli 2010: 3) mengatakan bahwa
Hukum ketenagakerjaan telah "berselingkuh" dengan para kapitalis, pengusaha. Sebagaimana yang kita tahu kapitalisme identik dengan kaum laki-laki dan Kapitalisme identik dengan pemupukan modal. Sehingga, dalam kerangka kapitalisme, perempuan adalah alat produksi yang paling murah dan bisa memaksimalkan keuntungan bagi mereka.

Jadi dapat disimpulkan alasan kenapa waktu cuti melahirkan memiliki rentang waktu yang sedikit bukan bertujuan untuk melindungi pekerja perempuan agar posisinya tetap aman atau karena pekerja perempuan pada posisi itu sangat penting, tetapi alasan yang lebih masuk akal adalah karena Perusahaan belum siap untuk ditinggalkan oleh aset berharganya (karyawan perempuan) dan mengalami kerugian akibat ditingggal cuti.

Apabila kebijakan cuti melahirkan diperpanjang menjadi 6 bulan bukan berarti permasalahan telah usai. Untuk tercapainya maksud dan tujuan dari memperpanjang cuti melahirkan (tercipta kedekatan emosional yang kuat antara ibu dan anak, ASI ekslusif mesti terlaksana, kesehatan pekerja lebih terjamin karena hanya fokus dalam merawat anak) maka diperlukannya kebijakan lain untuk menghilangkan kecenderungan depresi pasca melahirkan yang banyak terjadi pada ibu, yakni memperpanjang masa cuti bagi seorang suami dikarenakan istri melahirkan.

Berdasarkan Pasal 93 ayat 4 huruf e Undang-Undang nomer 13 tahun 2003 tentang ketenagakerjaan, seorang pekerja laki-laki hanya mendapatkan 2 hari masa cuti yang dibayar penuh sedangkan untuk mendapatkan waktu lebih seorang karyawan harus mengambil masa cuti tahunannya dan tidak mendapatkan bayaran. Waktu 2 hari dengan jaminan dibayar penuh tidaklah cukup. Agar seorang suami dapat membantu istrinya diawal-awal masa kelahiran maka Perusahaan setidaknya memberikan waktu 
lebih lama disertai jaminan dibayar penuh atas gajinya.

Merupakan stigma umum bahwa seorang suami bertugas untuk mencari nafkah. Alangkah sulitnya ketika suami membantu istrinya di awalawal masa kelahiran bayi tetapi ia tidak memiliki keuangan yang cukup. Padahal, keuangan saat awal masa kelahiran bayi sangatlah rentan; membayar biaya bersalin, membelikan keperluan bayi dan istri, dan tetap harus dapat menafkahi keluarganya merupakan sebuah hal yang tidak murah dan harus ada perhitungan khusus untuk mengantisipasi krisis keungan yang terjadi. Dengan memberikan waktu cuti melahirkan lebih lama dengan jaminan gaji dibayar penuh, setidaknya seorang suami merasa nyaman untuk membantu istrinya.

Keberadaan seorang suami di dekat istri pasca melahirkan dapat berfungsi sebagai bentuk dukungan untuk mengurangi beban psikologis istrinya. Tugas merawat dan membesarkan seorang anak bukan hanya tugas seorang ibu melainkan ayah turut mengambil andil besar di dalamnya. Seorang suami yang mengambil cuti melahirkan atau Paternity Leave setidaknya dituntut untuk mengurangi beban psikologis dan fisik yang dialami seorang ibu pasca melahirkan. Dukungan kepada istri bisa berupa memberikan motivasi, mengerjakan pekerjaan rumah, memberikan informasi terkait cara merawat bayi, dan menyarankan istri untuk menjaga kesehatan dan makananya (Ratu ayu dan Lailatushifah, 2008).

Untuk mewujudkan generasi yang lebih siap dan lebih baik maka diperlukannya kerja sama dan dukungan di antara banyak pihak. Dalam kasus ini, Pemerintah harus melegalkan Undang-Undang mengenai cuti melahirkan selama 6 bulan dan bertindak sebagai pengawas dan pelaksana. Perusahaan harus menjamin terpenuhinya hak tersebut dan seorang pekerja berhak mendapatkan posisi yang sama setelah masa cutinya selesai. Sedangkan suami dan keluarga memberikan motivasi dan saran kepada seorang ibu agar tidak mengalami depresi.

\section{PENUTUP}

\section{Simpulan}

Terbukti bahwa Perusahaan belum dapat mengimplementasikan kebijakan dalam menyelenggarakan Ruang ASI yang hiegenis dan memadai. Hal ini bisa dilihat berdasarkan hasil kuisoner terhadap fasilitas-fasilitas penting yang tidak tersedia, seperti: tidak adanya westafel untuk mencuci tangan dan peralatan, tidak adanya ruangan dengan meja dan kursi yang nyaman yang digunakan oleh pekerja selama memerah dan tidak adanya lemari pendingin untuk menaruh hasil perahan ASI.

Mengacu kepada teori terbentuk dan keluarnya ASI yakni refleks let down maka kebijakan memperpanjang masa cuti melahirkan dalam memberikan ASI ekslusif kepada anak lebih manusiawi bila dibandingkan dengan membuat peraturan-peraturan baru lainnya berkaitan dengan memerah atau Ruang ASI. Pertama, ASI yang diberikan lebih higienis. Kedua, terjalin kedekatan emosional di antara ibu dan anak. Ketiga, ibu yang tidak bekerja akan memiliki tingkat stres yang sedikit karena tidak berurusan dengan hal-hal di luar merawat dan mengasuh anak yang menyebabkan stres bertambah.

Peran seorang suami dalam memotivasi dan membantu istri pasca melahirkan sangatlah diperlukan untuk mengurangi tingkat depresi pada istri. Karena ketika istri mengalami depresi, maka akan menganggu proses tumbuh kembang anak.

\section{Saran}

Mengingat banyaknya terjadi penyimpangan terhadap kebijakan dalam menyediakan Ruang ASI maka seharusnya Pemerintah mempertimbangkan untuk merevisi 
kebijakan Ruang ASI. Dalam hal ini alangkah lebih baik Ruang ASI menjadi program tambahan setelah memberikan cuti melahirkan selama 6 bulan dan Ruang ASI menjadi program tambahan untuk membantu seorang ibu memberikan ASI selama 2 tahun lamanya.

Pemerintah atau Perusahaan harus memperbolehkan agar seorang karyawan dapat mengambil cuti melahirkan 6 bulan lamanya. Dan, Perusahaan wajib untuk membayarkan secara gaji bagi seoranga karyawati yang cuti melahirkan secara penuh selama 6 bulan. Apabila Perusahaan tidak sanggup secara finansial maka Pemerintah harus menyiapkan sebuah lembaga swasta atau Pemerintah yang fungsinya untuk membayarkan gaji kepada pekerjanya yang mengambil cuti melahirkan selama 6 bulan apabila Perusahaan sebagai tempatnya bekerja tidak sanggup untuk membiayai secara finansial agar kebijakan ini berjalan dengan baik. Dana bisa dihimpun selayaknya sebuah Asuransi yang diambil dari gaji karyawan, dengan catatan gaji seorang karyawati harus sudah melebihi setengah dari Upah Minimum Regional (UMR) yang diterapkan.

Pemerintah dan Perusahaan sebaiknya meninjau kembali untuk memberikan waktu paterternity leave yang lebih lama bagi seorang karyawan yang baru memiliki anak. Mengingat seorang perempuan memiliki kecenderungan untuk mengalami depresi pasca melahirkan maka seorang suami harus bisa memberikan masukan dan memotivasi istrinya agar tidak mengalami depresi yang berkelanjutan.

\section{DAFTAR PUSTAKA}

Agusmidah. Hukum Ketenagakerjaan Indonesia. Bogor: Penerbit Ghalia Indonesia, 2010.

Boediman, Drajat. Sehat Bersama Gizi. Materi bacaan dan Penyuluhan Gizi untuk masyarakat. Jakarta: Sagung Seto. 2009.
C.S.T. Kansil. Pengantar Ilmu Hukum dan Tata Hukum Indonesia. Jakarta: Balai Pustaka, 1986.

Machfuddin, Emfud. "Patofisiologi Pembentukan ASI." http://digilib.unsri.ac.id/download/patofisi ologi\%20laktasi.pdf (diakses 24 September 2015).

Moore, D. "Post-partum Depression." http://www.drdonnica.com/display.asp?arti cle $=154$ (diakses 24 September 2015).

Oxford Reference Online. "Feminist Legal Theory."

http://www.oxfordreference.com/view/10. 1093/oi/authority.20110803095814226 (diakses 4 September 2015).

Peraturang Menteri Kesehatan Republik Indonesia (Permenkes) tentang tata cara penyediaan fasilitas khusus menyusui dan/atau memerah air susu ibu, Peraturan Menteri Kesehatan Republik Indonesia (Permenkes) Nomor 15 tahun 2013.

Savitri, Niken. "Feminist Legal Theory dalam Teori Hukum," Permpuan dan Hukum: Menuju Hukum Yang Berperspektif Kesetaraan dan Keadilan, ed. Sulistyowati Irianto. Jakarta: Yayasan Obor Indonesia, 2006.

Sofiani, Triana. "Dari Hukum Seksis menuju Non-Seksis," PALESTReN Vol.3, No. 1, (Juli 2010), hal. 51-71.

Ratu Ayu, Fitria dan Siti Noor Fatmah Lailatushifah. "Dukungan suami dan depresi pasca melahirkan.” http://fpsi.mercubuana-yogya.ac.id/wpcontent/uploads/2012/06/jurnal-noor2008_depreso-pasca-melahirkan.pdf (diakses 24 September 2015).

Undang-Undang tentang Ketenagakerjaan, Undang-Undang Nomor 13 Tahun 2003. 